Zeszyty Naukowe Szkoły Głównej Gospodarstwa Wiejskiego w Warszawie Problemy Rolnictwa Światowego tom 17 (XXXII), zeszyt 2, 2017: 199-210

DOI: 10.22630/PRS.2017.17.2.39

Karolina Pawlak ${ }^{1}$

Uniwersytet Przyrodniczy w Poznaniu

\title{
Znaczenie wymiany bilateralnej w handlu zagranicznym produktami rolno-spożywczymi UE i USA ${ }^{2}$
}

\section{The Importance of the Bilateral Turnover to the EU and the US Foreign Trade in Agri-food Products}

\begin{abstract}
Synopsis. Celem artykułu było określenie znaczenia wymiany bilateralnej w handlu zagranicznym produktami rolno-spożywczymi UE i USA w latach 2001-2016 oraz wskazanie potencjalnych możliwości jej rozwoju w warunkach implementacji TTIP. W badaniach wykorzystano dane pochodzące $\mathrm{z}$ baz ComExt w zasobach Urzędu Statystycznego Unii Europejskiej (Eurostat) oraz Global Agricultural Trade System, pod nadzorem służb zagranicznych Departamentu Rolnictwa Stanów Zjednoczonych (FAS/USDA). Na podstawie przeprowadzonych analiz można stwierdzić, że w latach 2001-2016 UE i USA były dla siebie ważnymi partnerami handlowymi, jednak wartość bilateralnych obrotów produktami rolno-żywnościowymi pozostawała stosunkowo niewielka. W dużej mierze wynikało to $\mathrm{z}$ relatywnie niskiego stopnia komplementarności struktur produkcji rolniczej w tych krajach, a w rezultacie nieznacznego popytu na artykuły rolne strefy klimatu umiarkowanego w USA, które z powodzeniem, a zwykle także taniej są tam wytwarzane i które stanowią nadwyżki eksportowe tego kraju. Sposobem na zintensyfikowanie wzajemnych powiązań handlowych UE i USA może być utworzenie transatlantyckiej strefy wolnego handlu, skutkujące silnym efektem kreacji obrotów bilateralnych stron TTIP, przy jednoczesnym ograniczonym wpływie porozumienia na relacje z pozostałymi partnerami handlowymi.
\end{abstract}

Słowa kluczowe: produkty rolno-spożywcze, eksport, import, handel bilateralny, USA, UE, TTIP

Abstract. The aim of the paper was to assess the importance of the bilateral turnover to the EU and the US foreign trade in agri-food products in 2001-2016, as well as to define the possibilities of its development after signing the TTIP Agreement. The research is based on the data from the ComExt Database in the resources of the Statistical Office of the European Union (Eurostat) and the USDA Foreign Agricultural Service's Global Agricultural Trade System. It was proved that in 2001-2016 the EU and the US were important trade partners for each other, but the value of bilateral trade in agrifood products remained relatively small, largely due to low complementarity of the Polish and American agriculture and the resulting minor demand for agricultural products from the temperate zone in the US. These products are made in the US, usually at a lower cost, and they are the export surplus of this country. The way to intensify the EU-US bilateral trade may be to develop a transatlantic free trade area, resulting in a strong effect of trade creation between the TTIP parties, with a limited impact on the relationship with other trading partners.

Key words: agri-food products, export, import, bilateral trade, the US, the EU, the TTIP

\footnotetext{
${ }^{1}$ dr hab., prof. nadzw., Katedra Ekonomii i Polityki Gospodarczej w Agrobiznesie, Uniwersytet Przyrodniczy w Poznaniu, ul. Wojska Polskiego 28, 60-637 Poznań, e-mail: pawlak@up.poznan.pl

2 Artykuł współfinansowany przez Narodowe Centrum Nauki ze środków na naukę w ramach projektu badawczego z zakresu badań podstawowych OPUS nr 2015/17/B/HS4/00262, pt. Polski sektor rolnożywnościowy w warunkach implementacji Umowy o Transatlantyckim Partnerstwie Handlowym i Inwestycyjnym (TTIP).
} 


\section{Wprowadzenie}

Kraje UE i USA odgrywają istotną rolę w gospodarce światowej, jednak ich pozycja gospodarcza w końcu pierwszej dekady XXI w. uległa osłabieniu. O ile w 1995 roku gospodarki UE i USA wytwarzały łącznie prawie 60\% światowego PKB i w blisko 55\% uczestniczyły w globalnym eksporcie, o tyle w 2015 roku zaangażowanie badanych państw W generowanie realnego PKB na świecie obniżyło się o ponad 8 punktów procentowych, a udział $\mathrm{w}$ globalnym eksporcie zmniejszył o 12 punktów procentowych. W wymiarze bezwzględnym oznaczało to, że państwa UE wytworzyły PKB o wartości 15,9 bln USD, a z tytułu eksportu uzyskały przychody rzędu 5,4 bln USD. W tym samym roku wartość PKB w USA wyniosła 15,2 bln USD, a eksportu niemal 1,5 bln USD (UNCTAD, 2017). Przyczyną osłabienia pozycji UE i USA w światowej produkcji i wymianie handlowej był globalny kryzys gospodarczy w latach 2007-2009, który doprowadził do załamania handlu międzynarodowego i ograniczenia aktywności gospodarczej (Czarny i Śledziewska, 2012), a jednocześnie dynamiczny wzrost niektórych państw słabiej rozwiniętych, w tym krajów BRICS (Czarny, Menkes i Śledziewska, 2014). W 2015 roku wartość PKB, w cenach stałych 2005 roku, wytworzonego w krajach BRICS była o ponad 800 mld USD wyższa niż w UE i stanowiła $28 \%$ produktu światowego. W tym samym roku państwa BRICS realizowały niemal $20 \%$ światowego eksportu towarowego (3,2 bln USD), dwukrotnie przewyższając pod tym względem USA. W porównaniu z rokiem 1995 nastąpiło zwiększenie udziału krajów BRICS w globalnym PKB i eksporcie odpowiednio o blisko 21 i 13 punktów procentowych (UNCTAD, 2017).

Wobec obserwowanej zmiany układu sił gospodarczych, a w szczególności rosnącego znaczenia państw z regionu Azji i Pacyfiku, z Chinami na czele ${ }^{3}$, sposobu na utrzymanie silnej pozycji na rynku międzynarodowym upatruje się w pogłębieniu wzajemnych relacji gospodarczych UE i USA w ramach Umowy o Transatlantyckim Partnerstwie Handlowym i Inwestycyjnym (Transatlantic Trade and Investment Partnership - TTIP). Znaczenie wzajemnych związków gospodarczych stron TTIP w ujęciu ex post ocenili m.in. Czarny i Folfas (2016), natomiast potencjalne skutki implementacji Umowy były rozważane m.in. przez Felbermayr, Heid i Lehwald (2013), Fontagné, Gourdon i Jean (2013), Francois i in. (2013), Bureau i in. (2014), Pelkmans i in. (2014) oraz Felbermayr i in. (2015). Z jednej strony, dzięki utworzeniu największej jak dotąd na świecie międzyregionalnej strefy wolnego handlu, UE i USA mogą zwiększyć siłę oddziaływania na międzynarodowe otoczenie ekonomiczne i umocnić swoją pozycję względem państw BRICS. Z drugiej należy jednak pamiętać, że UE i USA różnią się istotnie pod względem potencjałów gospodarczych, a zawarcie porozumienia liberalizującego bilateralną wymianę handlowa może spowodować diametralną zmianę warunków konkurowania, zarówno na rynkach regionalnych, jak i rynku światowym. Ze względu na uwarunkowania historyczne, znaczące różnice potencjałów produkcyjnych (Pawlak, 2015) oraz asymetrię protekcji rynków (Pawlak, 2016), w sposób szczególny zmiana sytuacji konkurencyjnej może dotyczyć producentów i eksporterów artykułów rolno-żywnościowych.

Choć artykuły rolne nie zostały wyodrębnione w mandacie negocjacyjnym UE, stanowią jeden z najtrudniejszych obszarów rokowań TTIP. Podobnie jak na forum WTO,

\footnotetext{
${ }^{3}$ Analizy dotyczące wzrostu znaczenia Chin w gospodarce światowej prezentują m.in. Wang (2003), Bosworth i Collins (2008), Feenstra i Shang-Jin, red. (2010), Hölscher, Marelli i Signorelli (2010), Keller, Li i Shiue (2010) Cheptea (2012) oraz Paul (2016).
} 
rolnictwo jawi się jako „objęty najwyższa protekcją sektor gospodarek narodowych, najbardziej niezdyscyplinowany obszar handlu międzynarodowego i przyczyna najbardziej niebezpiecznych konfliktów w międzynarodowych stosunkach gospodarczych" (McCalla, 1993). Z badań Granta i Lamberta (2008) wynika jednak, że w liberalizowaniu wymiany artykułami rolnymi skuteczniejsze niż WTO były do tej pory regionalne porozumienia handlowe. Znaczące efekty kreacji handlu rolno-żywnościowego w krajach sygnatariuszy umów wolnohandlowych potwierdzili także Korinek i Melatos (2009), Lambert i McKoy (2009), Sun i Reed (2010) oraz Hndi, Maitah i Mustofa (2016). Uwzględniając rezultaty tych badań, można postawić pytanie, czy utworzenie międzyregionalnej strefy wolnego handlu UE-USA zaowocuje kreacją handlu i sprzyjać będzie umocnieniu przewag komparatywnych sektora rolno-żywnościowego po obu stronach Atlantyku, czy wręcz przeciwnie wyrównanie warunków konkurencji spowoduje, że w starciu z posiadającymi przewagi efektywnościowe i wynikające ze skali produkcji producentami i eksporterami amerykańskimi unijny sektor rolno-żywnościowy utraci czesść rynków, zarówno w regionie, jak i poza nim.

Skala efektów potencjalnej liberalizacji wymiany pomiędzy UE i USA w skali makroekonomicznej oraz na poziomie sektorowym będzie zdeterminowana przyjętym scenariuszem liberalizacji obrotów i uzależniona od stopnia zaangażowania partnerów w bilateralny handel. Stąd, celem artykułu jest określenie znaczenia wymiany bilateralnej w handlu zagranicznym produktami rolno-spożywczymi UE i USA w latach 2001-2016 oraz wskazanie potencjalnych możliwości jej rozwoju w warunkach implementacji TTIP.

\section{Dane i metody}

W badaniach wykorzystano dane pochodzące $\mathrm{z}$ baz ComExt $\mathrm{w}$ zasobach Urzędu Statystycznego Unii Europejskiej (Eurostat) oraz Global Agricultural Trade System pod nadzorem służb zagranicznych Departamentu Rolnictwa Stanów Zjednoczonych (FAS/USDA). Zastosowano metodę analizy opisowej wspartą tabelaryczną i graficzną prezentacją danych, metodę analogii i porównań oraz metodę wnioskowania dedukcyjnego.

Aby określić znaczenie wymiany bilateralnej $\mathrm{w}$ handlu zagranicznym produktami rolno-żywnościowymi UE i USA, sporządzono ranking najważniejszych partnerów eksportowych i importowych badanych państw, pozycjonując wśród nich gospodarki stron TTIP. Analizie poddano również wartość, saldo obrotów i strukturę asortymentową handlu bilateralnego UE z USA w latach 2001-2016 roku, szacując udziały USA w wymianie UE ogółem i z krajami trzecimi. Zakres czasowy badań został zdeterminowany dostępnością kompletnych i porównywalnych w skali międzynarodowej danych. W układzie asortymentowym analize przeprowadzono na poziomie sekcji Scalonej Nomenklatury Towarowej Handlu Zagranicznego (Combined Nomenclature - CN).

Możliwości rozwoju handlu produktami rolno-żywnościowymi pomiędzy krajami UE i USA, na skutek implementacji TTIP, omówiono z wykorzystaniem metody metaanalizy. Przedstawiono wyniki analiz symulacyjnych wykonanych $w$ warunkach równowagi ogólnej, przy założeniu że w handlu transatlantyckim nastapi całkowita eliminacja ceł i 25procentowa redukcja barier pozataryfowych $w$ handlu wszystkimi towarami i usługami. 


\section{Handel bilateralny produktami rolno-spożywczymi UE z USA w latach 2001-2016}

W latach 2001-2016 wartość eksportu produktów rolno-spożywczych z krajów UE do USA zwiększyła się prawie 2-krotnie, osiaggając w ostatnim badanym roku niemal 20,7 mld euro (rys. 1). Mniej dynamiczny był wzrost importu żywności. W 2016 roku wartość przywozu artykułów rolnych i wyrobów przemysłu spożywczego z USA do UE wyniosła blisko 11,7 mld euro i była o około $36 \%$ wyższa niż w roku 2001. Co istotne, w całym analizowanym okresie UE zajmowała pozycję eksportera netto artykułów rolnożywnościowych z USA, a pomijając lata, w których ujawnił się globalny kryzys gospodarczy i rok 2013, kiedy tempo wzrostu gospodarczego ponownie uległo osłabieniu ${ }^{4}$, notowane dodatnie saldo obrotów systematycznie zwiększało się. W 2016 roku wartość eksportu produktów rolno-spożywczych z UE do USA przewyższała wartość przywozu o 9 mld euro, a uzyskiwana nadwyżka handlowa była prawie 4,5 razy większa w porównaniu z rokiem 2001

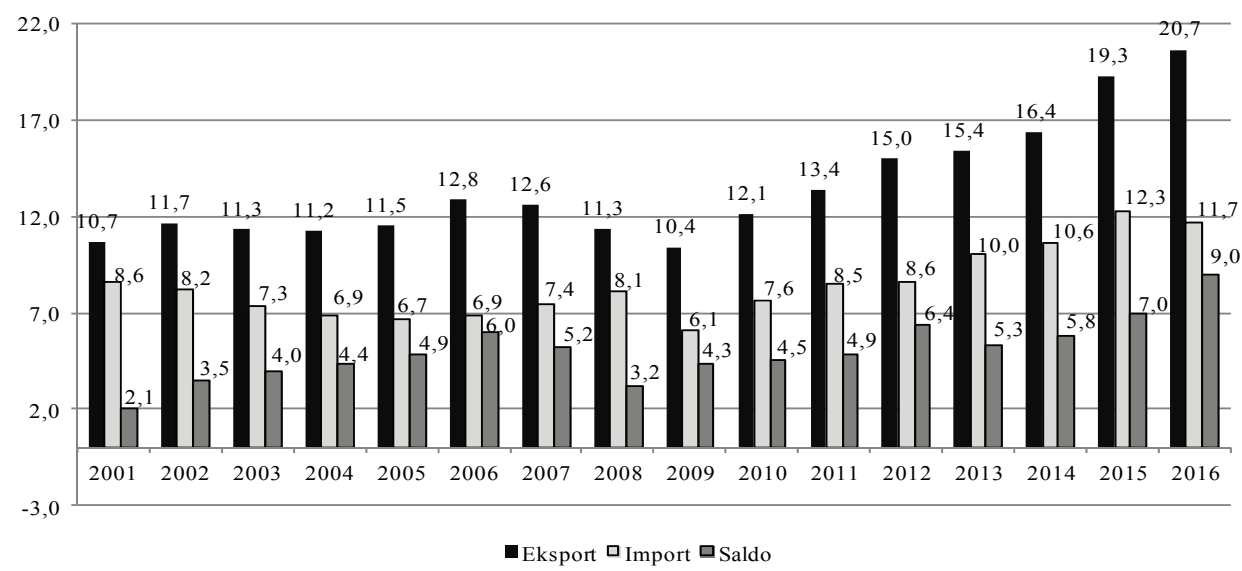

Rys. 1. Handel bilateralny produktami rolno-spożywczymi UE z USA w latach 2001-2016 (mld euro)

Fig. 1. Bilateral trade in agri-food products between the EU and the US in 2001-2016 (billion euro)

Źródło: (ComExt-Eurostat 2017), opracowanie własne.

Można stwierdzić, że choć UE i USA są dla siebie ważnymi partnerami handlowymi, wartość bilateralnych obrotów artykułami rolno-żywnościowymi pozostawała stosunkowo niewielka, a znaczenie partnerów w strukturze wymiany ogółem zmniejszało się. Zarówno w 2001, jak i w 2016 roku USA były dla UE siódmym pod względem wartości wywozu partnerem eksportowym i pierwszym wśród krajów pozaunijnych (tab. 1). W ostatnim analizowanym roku udział USA w eksporcie UE ogółem ukształtował się na poziomie nieco ponad $4 \%$, a w eksporcie do państw trzecich wyniósł $16 \%$, tj. odpowiednio o około 0,5 oraz 4 punkty procentowe mniej niż w roku 2001 (tab. 3). W imporcie USA były dla UE drugim spośród krajów pozaunijnych, po Brazylii, partnerem handlowym (tab. 2).

${ }^{4}$ W 2013 roku tempo wzrostu PKB w USA wyniosło 1,67\% i było o 0,54 punktu procentowego niższe niż w roku 2012 (UNCTAD, 2017) 
Tabela 1. Eksport produktów rolno-spożywczych z UE według ważniejszych partnerów handlowych w latach 2001 i 2016 (z uwzględnieniem partnerów w handlu wewnątrzwspólnotowym)

Table 1. Export of agri-food products from the EU by major trade partners in 2001 and 2016 (including intra-EU partners)

\begin{tabular}{|c|c|c|c|c|c|c|c|}
\hline \multirow{2}{*}{ Lp. } & \multicolumn{3}{|c|}{2001} & \multirow{2}{*}{ Lp. } & \multicolumn{3}{|c|}{2016} \\
\hline & Kraj & Mld euro & $\%$ & & Kraj & Mld euro & $\%$ \\
\hline 1 & Niemcy & 37,3 & 16,1 & 1 & Niemcy & 68,3 & 13,7 \\
\hline 2 & Francja & 23,6 & 10,2 & 2 & Francja & 43,1 & 8,7 \\
\hline 3 & Wielka Brytania & 21,8 & 9,4 & 3 & Wielka Brytania & 40,3 & 8,1 \\
\hline 4 & Włochy & 18,4 & 7,9 & 4 & Holandia & 32,6 & 6,6 \\
\hline 5 & Holandia & 15,4 & 6,7 & 5 & Włochy & 30,1 & 6,0 \\
\hline 6 & Belgia & 12,9 & 5,6 & 6 & Belgia & 24,7 & 5,0 \\
\hline 7 & Stany Zjednoczone & 10,7 & 4,6 & 7 & Stany Zjednoczone & 20,7 & 4,2 \\
\hline 8 & Hiszpania & 9,9 & 4,3 & 8 & Hiszpania & 19,6 & 3,9 \\
\hline 9 & Japonia & 4,5 & 1,9 & 9 & Polska & 15,2 & 3,1 \\
\hline 10 & Austria & 4,3 & 1,9 & 10 & Austria & 10,9 & 2,2 \\
\hline & Ogółem & 230,9 & 100,0 & & Ogółem & 497,3 & 100,0 \\
\hline
\end{tabular}

Źródło: (ComExt-Eurostat 2017), obliczenia własne.

Tabela 2. Import produktów rolno-spożywczych do UE według ważniejszych partnerów handlowych w latach 2001 i 2016 (z uwzględnieniem partnerów w handlu wewnątrzwspólnotowym)

Table 2. Import of agri-food products to the EU by major trade partners in 2001 and 2016 (including intra-EU partners)

\begin{tabular}{|c|c|c|c|c|c|c|c|}
\hline \multirow{2}{*}{ Lp. } & \multicolumn{3}{|c|}{2001} & \multirow{2}{*}{ Lp. } & \multicolumn{3}{|c|}{2016} \\
\hline & Kraj & Mld euro & $\%$ & & Kraj & Mld euro & $\%$ \\
\hline 1 & Holandia & 33,8 & 14,1 & 1 & Holandia & 64,3 & 13,0 \\
\hline 2 & Francja & 26,5 & 11,1 & 2 & Niemcy & 56,1 & 11,3 \\
\hline 3 & Niemcy & 25,3 & 10,6 & 3 & Francja & 38,8 & 7,9 \\
\hline 4 & Hiszpania & 15,4 & 6,4 & 4 & Hiszpania & 32,8 & 6,6 \\
\hline 5 & Belgia & 14,9 & 6,2 & 5 & Belgia & 31,0 & 6,3 \\
\hline 6 & Włochy & 12,1 & 5,1 & 6 & Włochy & 25,0 & 5,1 \\
\hline 7 & Wielka Brytania & 10,1 & 4,2 & 7 & Polska & 19,6 & 4,0 \\
\hline 8 & Brazylia & 8,9 & 3,7 & 8 & Wielka Brytania & 16,8 & 3,4 \\
\hline 9 & Stany Zjednoczone & 8,6 & 3,6 & 9 & Dania & 12,6 & 2,6 \\
\hline 10 & Dania & 8,3 & 3,5 & 10 & Brazylia & 11,8 & 2,4 \\
\hline 11 & Irlandia & 5,7 & 2,4 & 11 & Stany Zjednoczone & 11,7 & 2,4 \\
\hline & Ogółem & 239,2 & 100,0 & & Ogółem & 494,4 & 100,0 \\
\hline
\end{tabular}

Źródło: (ComExt-Eurostat 2017), obliczenia własne. 
Tabela 3. Handel bilateralny produktami rolno-spożywczymi UE z USA według sekcji CN w latach 2001 i 2016

Table 3. Bilateral trade in agri-food products between the EU and the US by CN section in 2001 and 2016

\begin{tabular}{|c|c|c|c|c|c|c|c|c|c|}
\hline $\begin{array}{l}\text { Sekcja } \\
\text { CN }\end{array}$ & Mld euro & $\%$ & $\begin{array}{l}\text { ksport } \\
\text { Udział w } \\
\text { eksporcie } \\
\text { UE } \\
\text { ogółem } \\
(\%)\end{array}$ & $\begin{array}{l}\text { Udział w } \\
\text { eksporcie } \\
\text { UE do } \\
\text { krajów } \\
\text { trzecich } \\
(\%)\end{array}$ & Mld euro & $\%$ & $\begin{array}{l}\text { Iport } \\
\text { Udział w } \\
\text { imporcie } \\
\text { UE } \\
\text { ogółem } \\
(\%)\end{array}$ & $\begin{array}{c}\text { Udział w } \\
\text { imporcie } \\
\text { UE z } \\
\text { krajów } \\
\text { trzecich } \\
(\%)\end{array}$ & $\begin{array}{r}\text { Saldo } \\
\text { (mld } \\
\text { euro) }\end{array}$ \\
\hline \multicolumn{10}{|c|}{2001} \\
\hline I & 1,3 & 11,7 & 2,0 & 10,4 & 1,0 & 11,1 & 1,5 & 5,9 & 0,3 \\
\hline II & 1,3 & 11,9 & 2,3 & 12,9 & 3,7 & 43,4 & 5,5 & 14,2 & $-2,5$ \\
\hline III & 0,4 & 4,0 & 5,5 & 19,7 & 0,2 & 2,3 & 2,4 & 8,0 & 0,2 \\
\hline IV & 7,7 & 72,3 & 7,3 & 25,5 & 3,7 & 43,3 & 3,8 & 15,2 & 4,0 \\
\hline Ogółem & 10,7 & 100,0 & 4,6 & 19,6 & 8,6 & 100,0 & 3,6 & 12,4 & 2,1 \\
\hline \multicolumn{10}{|c|}{2016} \\
\hline I & 2,5 & 11,9 & 2,0 & 9,0 & 1,3 & 11,3 & 1,1 & 5,0 & 1,1 \\
\hline II & 2,3 & 11,4 & 2,0 & 9,2 & 6,2 & 53,2 & 4,3 & 11,8 & $-3,9$ \\
\hline III & 1,2 & 5,7 & 5,3 & 21,3 & 0,4 & 3,8 & 1,7 & 4,8 & 0,7 \\
\hline IV & 14,7 & 71,0 & 6,3 & 20,4 & 3,7 & 31,7 & 1,8 & 8,4 & 11,0 \\
\hline Ogółem & 20,7 & 100,0 & 4,2 & 15,9 & 11,7 & 100,0 & 2,4 & 8,8 & 9,0 \\
\hline
\end{tabular}

Objaśnienia: I - zwierzęta żywe, produkty pochodzenia zwierzęcego; II - produkty pochodzenia roślinnego; IIIoleje i tłuszcze; IV - przetwory spożywcze

Źródło: (ComExt-Eurostat 2017), obliczenia własne.

W latach 2001 i 2016, z rynku amerykańskiego sprowadzano do UE odpowiednio około $12,5 \%$ oraz $9 \%$ żywności nabywanej poza UE. W strukturze przywozu ogółem udział USA, mimo wspomnianego wzrostu wartości importu w wymiarze bezwzględnym, uległ obniżeniu do niespełna 2,5\% w 2016 roku (tab. 3). USA stały się dla UE 11 partnerem importowym, a w stosunku do 2001 roku wyprzedziły je Polska i Dania (tab. 2).

Znaczenie UE w handlu produktami rolno-spożywczymi USA było relatywnie większe. W latach 2001 i 2016 kraje UE były czwartym, co do wartości obrotów, odbiorcą artykułów rolno-żywnościowych z USA oraz pierwszym ich dostawcą (tab. 4 i 5). W 2016 roku eksport na rynki państw UE stanowił niemal 9\%, a import 21,5\% łącznej wartości wywozu i przywozu produktów rolno-spożywczych z/do USA. Większych niż kraje UE zakupów żywności dokonywały na rynku amerykańskim jedynie Japonia, Kanada i Meksyk, a w 2016 roku także Chiny. USA eksportowały produkty rolno-spożywcze głównie do krajów UE-15, w tym przede wszystkim do Holandii, Wielkiej Brytanii, Niemiec, Hiszpanii, Włoch i Belgii. Dominowały wśród nich artykuły pochodzenia roślinnego oraz przetwory spożywcze. Łącznie odpowiadały one za około 85\% wartości przywozu z USA do UE (tab. 3). Należy zwrócić uwagę, że o ile wymianie produktami przemysłu spożywczego towarzyszyła rosnąca nadwyżka obrotów (z 4 mld euro w 2001 roku do 11 mld euro w 2016 roku), w handlu artykułami roślinnymi notowano pogłębiający się deficyt, który w 2016 roku wyniósł prawie 4 mld euro. Wynikał on z relatywnie niewielkiej komplementarności struktur produkcji rolniczej $\mathrm{w}$ badanych krajach, a w 
rezultacie nieznacznego popytu na produkty rolne strefy klimatu umiarkowanego w USA, które z powodzeniem, a zwykle także taniej są tam wytwarzane i które stanowią nadwyżki eksportowe tego kraju. Istotnymi pozycjami w przywozie artykułów pochodzenia roślinnego z USA do UE były owoce i orzechy (pistacje i migdały) oraz nasiona oleistych (soja). Spośród przetworów spożywczych z USA do UE importowano przede wszystkim pozostałości i odpady przemysłu spożywczego, w tym głównie produkty uboczne ekstrakcji oleju sojowego, gotową paszę dla zwierząt, tytoń i przemysłowe namiastki tytoniu oraz napoje alkoholowe (wina i whisky).

Tabela 4. Eksport produktów rolno-spożywczych z USA według ważniejszych partnerów handlowych w latach 2001 i $2016^{\mathrm{a}}$

Table 4. Export of agri-food products from the US by major trade partners in 2001 and $2016^{\mathrm{a}}$

\begin{tabular}{|c|c|c|c|c|c|c|c|}
\hline \multirow{2}{*}{ Lp. } & \multicolumn{3}{|c|}{2001} & \multirow{2}{*}{ Lp. } & \multicolumn{3}{|c|}{2016} \\
\hline & Kraj & Mld euro & $\%$ & & Kraj & Mld euro & $\%$ \\
\hline 1 & Japonia & 11,7 & 17,9 & 1 & Kanada & 22,7 & 17,3 \\
\hline 2 & Kanada & 10,3 & 15,6 & 2 & Chiny & 19,7 & 15,1 \\
\hline 3 & Meksyk & 8,6 & 13,1 & 3 & Meksyk & 16,7 & 12,8 \\
\hline 7 & Holandia & 1,6 & 2,4 & 8 & Holandia & 2,7 & 2,1 \\
\hline 9 & Wielka Brytania & 1,3 & 2,0 & 13 & Wielka Brytania & 1,9 & 1,5 \\
\hline 10 & Niemcy & 1,1 & 1,7 & 14 & Niemcy & 1,6 & 1,2 \\
\hline 15 & Hiszpania & 0,8 & 1,2 & 16 & Hiszpania & 1,4 & 1,1 \\
\hline 16 & Belgia & 0,8 & 1,2 & 26 & Włochy & 0,9 & 0,7 \\
\hline 19 & Włochy & 0,7 & 1,0 & 31 & Belgia & 0,7 & 0,6 \\
\hline & UE-28 & 8,3 & 12,6 & & UE-28 & 11,4 & 8,7 \\
\hline & Ogółem & 65,6 & 100,0 & & Ogółem & 130,8 & 100,0 \\
\hline
\end{tabular}

a - wartość eksportu USA do UE nie jest równa wartości importu UE z USA ze względu na kalkulowanie cen w eksporcie według formuły fob, a w imporcie według formuły cif

Źródło: (GATS 2017; NBP 2017), obliczenia własne.

Ponad 70\% całości przychodów z tytułu eksportu na rynek amerykański (blisko 15 mld euro w 2016 roku) zapewniały UE przetwory spożywcze. Warto podkreślić, że do USA trafiało około $20-25 \%$ eksportu tej grupy produktów na rynki pozaunijne (tab. 3). W przeważającej mierze były to napoje alkoholowe, posiadające około 50-procentowy udział $\mathrm{w}$ strukturze eksportu żywności z UE do USA, a także przetwory zbożowe i owocowo-warzywne. Poza tym, do USA sprowadzano z UE produkty mleczarskie (głównie sery). W 2016 roku na zakup tego asortymentu przeznaczono ponad 5\% łącznych wydatków na przywóz żywności z UE (GATS, 2017). Z uwagi na tak ukształtowaną strukturę asortymentową wymiany, wśród najważniejszych dostawców artykułów rolnospożywczych do USA znalazły się Francja, Włochy, Irlandia, Wielka Brytania i Holandia (tab. 5). 
Tabela 5. Import produktów rolno-spożywczych do USA według ważniejszych partnerów handlowych w latach 2001 i $2016^{\mathrm{a}}$

Table 5. Import of agri-food products to the US by major trade partners in 2001 and $2016^{\mathrm{a}}$

\begin{tabular}{|c|c|c|c|c|c|c|c|}
\hline \multirow{2}{*}{ Lp. } & \multicolumn{3}{|c|}{2001} & \multirow{2}{*}{ Lp. } & \multicolumn{3}{|c|}{2016} \\
\hline & Kraj & Mld euro & $\%$ & & Kraj & Mld euro & $\%$ \\
\hline 1 & Kanada & 12,1 & 23,3 & 1 & Meksyk & 22,7 & 19,4 \\
\hline 2 & Meksyk & 6,6 & 12,7 & 2 & Kanada & 20,3 & 17,4 \\
\hline 3 & Francja & 2,5 & 4,7 & 3 & Francja & 5,1 & 4,3 \\
\hline 7 & Holandia & 2,1 & 4,1 & 4 & Włochy & 4,4 & 3,8 \\
\hline 9 & Włochy & 2,0 & 3,9 & 8 & Irlandia & 3,2 & 2,7 \\
\hline 10 & Wielka Brytania & 1,6 & 3,0 & 10 & Wielka Brytania & 2,5 & 2,2 \\
\hline 15 & Niemcy & 1,0 & 1,9 & 12 & Holandia & 2,4 & 2,0 \\
\hline 16 & Hiszpania & 0,9 & 1,7 & 19 & Niemcy & 1,9 & 1,6 \\
\hline 19 & Irlandia & 0,6 & 1,1 & 20 & Hiszpania & 1,9 & 1,6 \\
\hline & UE-28 & 12,7 & 24,6 & & UE-28 & 25,2 & 21,5 \\
\hline & Ogółem & 51,8 & 100,0 & & Ogółem & 117,1 & 100,0 \\
\hline
\end{tabular}

a - wartość importu USA z UE nie jest równa wartości eksportu UE do USA ze względu na kalkulowanie cen w eksporcie według formuły fob, a w imporcie według formuły cif

Źródło: (GATS 2017; NBP 2017), obliczenia własne.

Poszukując, innych niż przewagi kosztowo-cenowe oraz wzajemny kurs wymienny walut, czynników determinujących wartość obrotów bilateralnych UE i USA można odwołać się do wyników badań Salvacruz i Reed (1993), którzy wskazują, że wartość eksportu produktów rolno-żywnościowych z USA do państw ich partnerów handlowych jest uzależniona m.in. od poziomu samowystarczalności żywnościowej w krajach importerów i maleje wraz ze wzrostem odległości rynku docelowego, a w rezultacie zwiększeniem kosztów transportu. Do innych czynników sprzyjających wzrostowi popytu importowego na artykuły rolne wytwarzane w USA można zaliczyć rosnące tempo wzrostu gospodarczego i poziom dochodów, stymulujące wzrost popytu na zróżnicowane produkty żywnościowe, który nie zawsze może być zaspokojony jedynie przy udziale produkcji krajowej (Mellor, 1982; Gehlhar i in., 2007). Wzrost dobrobytu ekonomicznego, pobudzający konsumpcję i różnicujący preferencje konsumentów ${ }^{5}$, można również uznać za czynniki pobudzające wzrost importu do USA.

\section{Potencjalne skutki implementacji TTIP dla rozwoju bilateralnego handlu rolno-spożywczego UE z USA}

Na podstawie wyników przeprowadzonych dotychczas analiz symulacyjnych można stwierdzić, że liberalizacja wymiany handlowej pomiędzy UE i USA, przejawiająca się całkowitą eliminacją ceł i 25-redukcją barier pozataryfowych w handlu wszystkimi

\footnotetext{
${ }^{5}$ Zgodnie z teorią zróżnicowania produktów, rozmiary i struktura międzynarodowych obrotów handlowych są pochodną postępującej dywersyfikacji produkcji przemysłowej i usług. Stopień tego zróżnicowania zwiększa się natomiast wraz ze wzrostem dochodów indywidualnych oraz dywersyfikacją popytu konsumentów (Misala, 2003)
} 
towarami i usługami, może spowodować istotny wzrost bilateralnych obrotów handlowych, szacowany w granicach od 30\% (Francois i in., 2013) do 50\% (Fontagné, Gourdon i Jean, 2013). Ponieważ efekt kreacji handlu jest tym silniejszy, im wyższy jest poziom ceł i innych barier handlowych przed utworzeniem strefy preferencyjnego handlu (ZielińskaGłębocka, 1998), większej dynamiki wzrostu wzajemnej wymiany handlowej można oczekiwać w sektorze rolno-żywnościowym (tab. 6).

Tabela 6. Możliwości rozwoju handlu zagranicznego produktami rolno-spożywczymi UE i USA w warunkach implementacji TTIP ${ }^{\text {a }}$, przy założeniu całkowitej eliminacji ceł i 25 -procentowej redukcji barier pozataryfowych w handlu wszystkimi towarami i usługami (zmiany w \%)

Table 6. Estimated impacts of TTIP on agri-food trade flows in the EU and the US ${ }^{\text {, }}$, when complete abolition of duties and a removal of $25 \%$ of the initial non-tariff barriers to trade (NTB) on all products and services is assumed (changes in \%)

\begin{tabular}{|c|c|c|c|c|c|c|c|c|}
\hline \multirow{3}{*}{ Eksporter } & \multirow{3}{*}{ Importer } & \multicolumn{3}{|c|}{ Handel ogółem } & \multicolumn{4}{|c|}{ Handel rolno-żywnościowy } \\
\hline & & \multirow{2}{*}{$\begin{array}{l}\text { Fontagné, } \\
\text { Gourdon i } \\
\text { Jean } \\
(2013)\end{array}$} & \multirow{2}{*}{$\begin{array}{c}\text { Francois } \\
\mathrm{i} \text { in. } \\
(2013)\end{array}$} & \multirow{2}{*}{$\begin{array}{c}\text { Bureau } \\
\text { i in. } \\
(2014)\end{array}$} & \multirow{2}{*}{$\begin{array}{c}\text { Fontagné, } \\
\text { Gourdon i } \\
\text { Jean } \\
(2013)\end{array}$} & \multicolumn{2}{|c|}{ Francois i in. (2013) } & \multirow{2}{*}{$\begin{array}{c}\text { Bureau } \\
\mathrm{i} \text { in. } \\
(2014)\end{array}$} \\
\hline & & & & & & $\begin{array}{l}\text { Produkty } \\
\text { rolne }\end{array}$ & $\begin{array}{c}\text { Artykuły } \\
\text { spożywcze }\end{array}$ & \\
\hline \multicolumn{9}{|c|}{ Handel transatlantycki } \\
\hline UE & USA & 49,0 & 28,0 & 37,3 & 149,5 & 15,1 & 45,5 & 56,4 \\
\hline USA & UE & 52,5 & 36,6 & 36,6 & 168,5 & 21,8 & 74,8 & 116,3 \\
\hline \multicolumn{9}{|c|}{ Pozostałe strumienie handlu } \\
\hline $\mathrm{UE}$ & $\begin{array}{l}\text { Pozostałe } \\
\text { kraje } \\
\text { świata }\end{array}$ & $-1,4$ & 5,9 & $-0,4$ & $-0,4$ & 0,2 & 9,4 & 0,0 \\
\hline USA & $\begin{array}{l}\text { Pozostałe } \\
\text { kraje } \\
\text { świata }\end{array}$ & $-1,4$ & 8,0 & $-1,7$ & $-1,9$ & 1,1 & 6,9 & $-1,5$ \\
\hline $\begin{array}{l}\text { Pozostałe } \\
\text { kraje } \\
\text { świata }\end{array}$ & UE & 0,2 & 5,1 & $-0,9$ & $-1,5$ & 5,2 & 10,1 & $-1,5$ \\
\hline $\begin{array}{l}\text { Pozostałe } \\
\text { kraje } \\
\text { świata }\end{array}$ & USA & $-2,5$ & 4,7 & $-1,2$ & $-0,8$ & 0,6 & 16,4 & $-1,7$ \\
\hline UE & UE & $-1,2$ & $\mathrm{x}$ & $-1,4$ & $-2,6$ & $\mathrm{x}$ & $\mathrm{x}$ & $-2,1$ \\
\hline \multicolumn{9}{|c|}{$\begin{array}{l}\text { a - projekcje Fontagné, Gourdon i Jean (2013) oraz Bureau i in. (2014) zostały zrealizowane przy użyciu modelu } \\
\text { MIRAGE; rezultaty symulacji przeprowadzonych przez oba zespoły badawcze różnią się z uwagi na zastosowanie } \\
\text { przez nie różnych metod szacowania taryfowych ekwiwalentów pozataryfowych instrumentów polityki } \\
\text { handlowej, a w konsekwencji różnych ich poziomów poddanych redukcji; analizy Francois i in. (2013) zostały } \\
\text { przeprowadzone z wykorzystaniem modelu równowagi ogólnej zbudowanego w oparciu o model GTAP } \\
\text { i zmodyfikowanego zgodnie z podejściem Francois, van Meijla i van Tongerena (2005) }\end{array}$} \\
\hline
\end{tabular}

W 2015 roku średnia arytmetyczna stawka celna KNU stosowana przez kraje UE w imporcie ogółem wynosiła 5,1\%, przy czym artykuły rolne były obciążone 2,5-krotnie wyższą stawką celną niż towary nierolnicze (w wysokości odpowiednio $10,7 \%$ oraz $4,2 \%$ ). Poziom protekcji taryfowej w USA był relatywnie niższy niż w państwach UE. W handlu ogółem przeciętna faktycznie stosowana stawka celna KNU kształtowała się na poziomie 
$3,5 \%$, w przywozie artykułów rolnych wynosiła 5,2\%, a nierolniczych $-3,2 \%$ (WTO, ITC, UNCTAD, 2016). Poza cłami, w handlu produktami rolno-żywnościowymi zarówno UE, jak i USA wykorzystują wysokie bariery pozataryfowe, głównie w postaci środków sanitarnych, fitosanitarnych oraz norm technicznych (Zob. Hagemejer, Michałek i Pawlak, 2016). Już częściowa rezygnacja ze stosowania tego rodzaju instrumentów mogłaby sprawić, że wywóz artykułów rolno-spożywczych z UE do USA zwiększyłby się w granicach od około 56\% (Bureau i in., 2014) do 150\% (Fontagné, Gourdon i Jean, 2013). Z racji wyższego poziomu protekcji celnej rynku UE, redukcja barier we wzajemnej wymianie UE-USA bardziej proeksportowo może oddziaływać na gospodarkę USA. W sytuacji całkowitej eliminacji ceł i 25 -procentowej redukcji barier pozataryfowych, import produktów rolnych z USA do UE mógłby się zwiększyć nawet o blisko $170 \%$. Francois i in. (2013) wskazują ponadto, że potencjalnie większa mogłaby być dynamika wzrostu bilateralnego handlu artykułami spożywczymi niż produktami rolnymi. Przewidywana silna ekspansja handlu transatlantyckiego, może wynikać nie tylko z kreacji nowych strumieni handlowych na skutek likwidacji istniejących wcześniej barier wymiany, a w rezultacie obniżenia cen, ale także wiązać się z efektem przesunięcia handlu - wywołaną zmianami cen relatywnych realokacją popytu $\mathrm{w}$ układzie wzajemnym UE-USA i ograniczeniem obrotów z krajami niebędącymi sygnatariuszami TTIP. Siła tego efektu nie powinna być jednak zbyt duża, a zmniejszenie eksportu i importu UE i USA do/z krajów trzecich nie powinno przekroczyć 3\% (tab. 6).

\section{Podsumowanie}

Z przeprowadzonych analiz wynika, że w latach 2001-2016 UE i USA były dla siebie ważnymi partnerami handlowymi, jednak wartość bilateralnych obrotów produktami rolnożywnościowymi pozostawała stosunkowo niewielka. W 2016 roku USA były dla UE siódmym pod względem wartości wywozu partnerem eksportowym i jedenastym w imporcie, przy czym biorąc pod uwage jedynie państwa spoza UE znaczenie USA jako partnera handlowego UE zwiększało się. Eksport o wartości sięgającej blisko 21 mld euro i import rzędu 12 mld euro, zapewniał USA odpowiednio pierwsze i drugie - po Brazylii miejsce wśród odbiorców i dostawców artykułów rolno-spożywczych z/do UE. Kraje UE, ustępując Kanadzie, Chinom i Meksykowi, były z kolei czwartym, co do wartości obrotów, odbiorcą produktów rolno-żywnościowych z USA oraz pierwszym ich dostawca. O systematycznym wzroście dodatniego salda obrotów notowanego przez UE $\mathrm{w}$ handlu $\mathrm{z}$ USA przesądzała wymiana przetworami spożywczymi, która zapewniała ponad $70 \%$ całości przychodów z tytułu eksportu na rynek amerykański.

Relatywnie mała wartość obrotów handlowych pomiędzy UE i USA wynikała w dużej mierze ze stosunkowo niskiego stopnia komplementarności struktur produkcji rolniczej w tych krajach, a w rezultacie nieznacznego popytu na artykuły rolne strefy klimatu umiarkowanego w USA, które z powodzeniem, a zwykle także taniej są tam wytwarzane i które stanowią nadwyżki eksportowe tego kraju. Wśród innych czynników determinujących rozwój bilateralnej wymiany handlowej produktami rolno-spożywczymi UE z USA można wymienić m.in. tempo wzrostu gospodarczego i zwiększenie dochodów dyspozycyjnych konsumentów, stymulujące wzrost popytu na zróżnicowane produkty żywnościowe, który nie zawsze może być zaspokojony tylko przy udziale produkcji krajowej. Z UE do USA eksportowano przede wszystkim napoje alkoholowe, przetwory 
zbożowe i owocowo-warzywne. Istotnymi pozycjami w przywozie artykułów spożywczych z USA do UE były natomiast owoce i orzechy, nasiona oleistych, pozostałości i odpady przemysłu spożywczego, w tym głównie produkty uboczne ekstrakcji oleju sojowego, gotowa pasza dla zwierząt, wyroby tytoniowe oraz napoje alkoholowe. W związku z powyższym można stwierdzić, że z UE nie były eksportowane do USA produkty wytwarzane przez podstawowe branże przemysłu spożywczego, jak również surowce rolne i produkty spożywane $\mathrm{w}$ stanie nieprzetworzonym. Realizowany import, $\mathrm{z}$ punktu widzenia dostępności produktów na rynku, miał z kolei w dużej mierze charakter niezbędny.

Utworzenie strefy wolnego handlu UE-USA może wywołać nie tyle efekt przesunięcia, co efekt kreacji handlu, z większą siłą ujawniający się $\mathrm{w}$ chronionym dotąd wysokimi barierami handlowymi sektorze rolno-żywnościowym niż w wymianie ogółem, a $\mathrm{z}$ racji wyższego poziomu protekcji celnej rynku UE, bardziej proeksportowo oddziałujący na gospodarkę USA niż UE. W związku z zachodzącym równolegle, na skutek zmian cen relatywnych, zmniejszeniem handlu rolno-żywnościowego UE i USA z pozostałymi partnerami handlowymi, można oczekiwać względnego wzrostu znaczenia badanych krajów w strukturze ich wymiany handlowej. Uwzględniając wyższy stopień koncentracji zasobów ziemi, korzystniejsze relacje między czynnikami produkcji, a w rezultacie przewagi wydajnościowe, jakimi dysponuje rolnictwo amerykańskie nad europejskim, można przypuszczać, że w rezultacie implementacji TTIP USA mogą stać się dla poszczególnych krajów UE poważnym konkurentem na wewnątrzwspólnotowym rynku produktów rolno-żywnościowych.

\section{Literatura}

Bosworth, B., Collins, S.M. (2008). Accounting for Growth: Comparing China and India. Journal of Economic Perspectives, 22(1), 45-66.

Bureau, J-Ch., Disdier, A-C., Emlinger, Ch., Felbermayr, G., Fontagné, L., Fouré, J., Jean S. (2014). Risks and opportunities for the EU agri-food sector in a possible EU-US trade agrement. CEPII Research Report No. 2014-01, Paris, CEPII. Pobrane 15 maja 2017 z: http://www.europarl.europa.eu/RegData/etudes/STUD/ 2014/514007/AGRI IPOL STU(2014)514007 EN.pdf.

Cheptea, A. (2012). Who gains and who loses from China's growth? Working Paper SMART-LERECO No. 12 03, Rennes, INRA. Pobrane 4 czerwca 2017 z: http://prodinra.inra.fr/ft?id=253DF455-63B8-40C7-AD50A5DBC3F11AFD.

ComExt-Eurostat. Pobrane 3 czerwca 2017 z: http://epp.eurostat.ec.europa.eu/newxtweb.

Czarny, E., Folfas, P. (2016). Unia Europejska i Stany Zjednoczone w globalnej produkcji i międzynarodowej współpracy gospodarczej a TTIP. W: E. Czarny, M. Słok-Wódkowska (red.) Partnerstwo Transatlantyckie. Wnioski dla Polski (s. 31-46). Warszawa: PWE.

Czarny, E., Menkes, J., Śledziewska, K. (2014). Umowa o Partnerstwie Handlowo-Inwestycyjnym między Stanami Zjednoczonymi a Unią Europejską jako narzędzie międzynarodowej współpracy gospodarczej. International Business and Global Economy, 33, 199-213.

Czarny, E., Śledziewska, K. (2012). Międzynarodowa współpraca gospodarcza w warunkach kryzysu. Warszawa: PWE

Feenstra, R.C., Shang-Jin, W. (red.). (2010). China's Growing Role in World Trade. Chicago and London: University of Chicago Press.

Felbermayr, G., Heid, B., Larch, M., Yalcin, E. (2015). Macroeconomic potentials of transatlantic free trade: a high resolution perspective for Europe and the world. Economic Policy, 30(83), 491-537.

Felbermayr, G., Heid, B., Lehwald, S. (2013). Transatlantic Free Trade: Winners, Losers and Necessary Accompanying Measures. Law and Business Review of the Americas, 19(4), 445-486.

Fontagné, L., Gourdon, J., Jean, S. (2013). Transatlantic Trade: Whither Partnership, Which Economic Consequences? CEPII Policy Brief No. 1, Paris, CEPII. Pobrane 15 maja 2017 z: http://www.cepii.fr/ pdf_pub/pb/2013/pb2013-01.pdf. 
Francois, J., Manchin, M., Norberg, H., Pindyuk, H., Tomberger, P. (2013). Reducing Trans-Atlantic Barriers to Trade and Investment. London, CEPR. Pobrane 15 maja 2017 z:http://rade.ec.europa.eu/doclib/docs/2013/ march/tradoc_150737.pdf.

Francois, J., van Meijl, H., van Tongeren, F. (2005). Trade liberalization in the Doha Development Round. Economic Policy, 20(42), 350-391.

Gehlhar, M., Dohlman, E., Brooks, N., Jerardo, A., Vollrath, T. (2007). Global Growth, Macroeconomic Change, and U.S. Agricultural Trade. Economic Research Report No. 46, Washington D.C, USDA, ERS.

Global Agricultural Trade System. Pobrane 3 czerwca 2017 z: https://apps.fas.usda.gov/gats/ExpressQuery1.aspx.

Grant, J.H., Lambert, D.M. (2008). Do Regional Trade Agreements Increase Members' Agricultural Trade? American Journal of Agricultural Economics, 90(3), 765-782.

Hagemejer, J., Michałek, J.J., Pawlak, K. (2016). Ocena wpływu podpisania TTIP na polski sektor rolny i spożywczy. W: M. Dunin-Wąsowicz (red.) Analiza wpływu TTIP na wybrane sektory polskiej gospodarki (s. 120-197). Warszawa: Wydawnictwo Naukowe SCHOLAR.

Hndi, B.M., Maitah, M., Mustofa, J. (2016). Trade Impacts of Selected Free Trade Agreements on Agriculture: The Case of Selected North African Countries. Agris on-line Papers in Economics and Informatics, 8(3), 39-50. DOI 10.7160/aol.2016.080304.

Hölscher, J., Marelli, E., Signorelli, M. (2010). China and India in the global economy. Economic Systems, 34(3), 212-217.

Keller, W., Li, B., Shiue, C.H. (2010). China's Foreign Trade: Perspectives From the Past 150 Years. NBER Working Paper No. 16550, Cambridge, NBER. Pobrane 15 maja 2017 z: http://www.nber.org/papers/ w16550.pdf.

Korinek, J., Melatos, M. (2009). Trade Impacts of Selected Regional Trade Agreements in Agriculture. OECD Trade Policy Working Papers No. 87. Paris: OECD.

Lambert, D., McKoy, S. (2009). Trade Creation and Diversion Effects of Preferential Trade Associations on Agricultural and Food Trade. Journal of Agricultural Economics, 60(1), 17-39.

McCalla, A.F. (1993). Agricultural Trade Liberalization: The Ever-Elusive Grail. American Journal of Agricultural Economics, 75(5), 1102-1112.

Mellor, J.W. (1982). Third World Development: Food, Employment, and Growth Interactions. American Journal of Agricultural Economics, 64(2), 304-311.

Misala, J. (2003). Współczesne teorie wymiany międzynarodowej i zagranicznej polityki ekonomicznej. Warszawa: Oficyna Wydawnicza SGH.

NBP. Archiwum kursów średnich - tabela A. Pobrane 3 czerwca 2017 z: http://www.nbp.pl/home.aspx?f=/ statystyka/kursy.html.

Paul, S. (2016). The Rise of China: What, When, Where and Why? The International Trade Journal, $30(3)$, 207222 .

Pawlak, K. (2015). Konkurencyjność zasobowa rolnictwa UE i USA. ZN SGGW Problemy Rolnictwa Światowego, $15(30)$, z. 3, 112-123.

Pawlak, K. (2016). Tariff barriers to the EU and the US agri-food trade in the view of the TTIP negotiation. Agrarian Perspectives XXV. Global and European Challenges for Food Production, Agribusiness and the Rural Economy, Proceedings of the 25th International Scientific Conference, Czech University of Life Sciences Prague, Faculty of Economics and Management, 14-16 September 2016, 244-250.

Pelkmans, J., Lejour, A., Schrefler, L., Mustilli, F., Timini, J. (2014). The impact of TTIP. The underlaying economic model and comparisons. CEPS Special Report No. 93. Brussels: Centre for European Policy Studies.

Salvacruz, J., Reed, M. (1993). Identifying the Best Market Prospects for US Agricultural Exports. Agribusiness, 9(1), 29-41.

Sun, L., Reed, M.R. (2010). Impacts of free trade agreements on agricultural trade creation and trade diversion. American Journal of Agricultural Economics, 92(5), 1351-1363.

UNCTAD. Data Center. Pobrane 3 czerwca 2017 z: http://unctadstat.unctad.org/wds/ReportFolders/report Folders.aspx?sCS_ChosenLang=en.

Wang, Z. (2003). The impact of China's WTO accession on patterns of world trade. Journal of Policy Modeling, $25(1), 1-41$.

WTO, ITC, UNCTAD (2016). World Tariff Profiles. Pobrane 21 stycznia 2017 z: https://www.wto.org/english/ res_e/booksp_e/tariff_profiles15_e.pdf.

Zielińska-Głębocka, A. (1998). Wprowadzenie do ekonomii międzynarodowej. Teoria handlu i polityki handlowej. Gdańsk: Wydawnictwo Uniwersytetu Gdańskiego. 